\title{
How Big History Could Change the World for the Better
}

\author{
Macquarie University, Big History Institute, Sydney, Australia
}

\begin{abstract}
Big History is ideally positioned to act as a major driver of social change through the promotion of a rigorous and accessible scientific origin story. This origin story appeals to our species' universal predilection for storytelling and unifies key scientific theories across disciplines within a single, coherent narrative. Below, I identify two interrelated problems that Big History can help combat: suboptimal cultural knowledge priorities, and scientific illiteracy. I then explore how Big History can be part of the solution, with reference to my own experience teaching Big History in Australia. I argue that if taught globally and promoted as a core part of the assumed knowledge of every culture, Big History could help facilitate a much needed shift towards a more enlightened, rational, scientifically literate, and future conscious society.
\end{abstract}

Correspondence | Elise Bohan, elise.bohan@students.mq.edu.au

Citation | Bohan, E.. (2019) How Big History Could Change the World for the Better. Journal of Big History, III(3); 37 - 45.

DOI | https://doi.org/10.22339/jbh.v3i3.3330

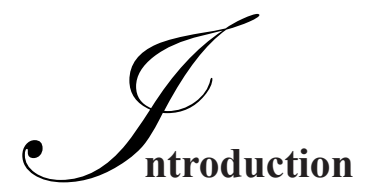

Contemplating the role of Big History in the social sphere is a crucial and ongoing task for big historians and one that must, at this early stage in the evolution of this academic culture, make reference to subjective opinions and anecdotal experiences. I hope this paper, and the others that appear in this collection, helps to start a conversation in the Big History community about our ongoing research, teaching and social outreach objectives. While Big History is unlikely to be a panacea for the world's ills, this paper is an argument for why we should think big when it comes to what we can achieve as teachers and researchers of this modern, scientific origin story. We should not underestimate the potential for a cultural shift in modern knowledge priorities to have major impacts down the line, perhaps even extending to our species' odds of ongoing survival.

\section{Knowledge Priorities and Scientific Literacy}

Our knowledge priorities in the Western world are currently skewed far too heavily towards things that don't matter much in terms of ongoing human and planetary survival, like sport, celebrity gossip, TV shows, and the theatre of partisan politics. Meanwhile, far more important issues, like existential risks, policy and funding priorities, and the promotion of scientific literacy, are massively underweighted. Most existential risks are not strongly politically prioritised and we still overwhelmingly favour short-term thinking and problem solving in the political arena (Bostrom 2002 \& 2013, Todd 2017).

Outside of professions where scientific literacy is essential, nobody bats an eyelid if you say that you hated science in school, or if you admit that you can't explain basic scientific concepts and terms like thermodynamics, or natural selection. On the contrary, people are likely to nod in vigorous agreement and bond with you over the fact that they also find science hard and boring (Pew Research Center 2013). But if you've never heard of Kim Kardashian, Shakespeare, Harry Potter, or Donald Trump, many people in the Western world would be flabbergasted to hear you admit it. These are names that everybody just knows. You don't have to know a great deal about the characters in question, but keeping a few factoids up your sleeve allows you to signal that you are an informed participant in modern Western culture and it reassures others that you have a basic sense of what's going on in the world. 
In contrast to the emphasis that we place on celebrity culture and human drama, few people seem to need reassuring at dinner parties, or in the office tea room, that you can explain terms like matter, or DNA, or that you know the difference between viruses and bacteria. C. P. Snow made a similar point over 50 years ago when he expressed consternation over the divide between the two intellectual cultures of the sciences and humanities. Of many humanities scholars, he noted:

They give a pitying chuckle at the news of scientists who have never read a major work of English literature. They dismiss them as ignorant specialists. Yet their own ignorance and their own specialisation is just as startling. A good many times I have been present at gatherings of people who, by the standards of the traditional culture, are thought highly educated and who have with considerable gusto been expressing their incredulity at the illiteracy of scientists. Once or twice I have been provoked and have asked the company how many of them could describe the Second Law of Thermodynamics. The response was cold: it was also negative. Yet I was asking something which is about the scientific equivalent of Have you read a work of Shakespeare's?

I now believe that if I had asked an even simpler question - such as, What do you mean by mass, or acceleration, which is the scientific equivalent of saying, Can you read? - not more than one in ten of the highly educated would have felt that I was speaking the same language. So the great edifice of modern physics goes up, and the majority of the cleverest people in the western world have about as much insight into it as their neolithic ancestors would have had (1959).

Snow's concerns about discpilinary siloisation and scientific illiteracy are as relevant today as they were in the 1950's. In a world where science and technology are major drivers of rapid economic growth and social change, it is more important than ever that the voting populace is informed about basic scientific concepts and that we are aware of how physical laws and phenomena have shaped the world around us, from the climate and ecology, to human nature itself. We don't need everyone to become scientists, but we should seek to bridge the growing chasm between how scientists and laypeople view the world, particularly with regards to how they reason and make decisions.

The greater the chasm between the knowledge of scientists and tech leaders, and that of the general public, the more likely our society is to fracture into tribes that speak past each other-right at a key historical moment when we need to unite in order to confront challenges on a global scale. Unfortunately, a knowledge chasm between scientists and the public already exists in the West. According to a recent Pew survey, $50 \%$ of Americans believe that climate change is mostly due to human activity, compared with $86 \%$ of scientists. $59 \%$ of Americans believe that a growing world population will be a major world problem, compared with $82 \%$ of scientists. $37 \%$ of Americans believe that it is safe to eat genetically modified foods, compared with $88 \%$ of scientists, while $65 \%$ of Americans believe humans have evolved over time compared with $98 \%$ of scientists (Pew 2015). In another representative survey of 1,000 Americans, $80 \%$ of respondents stated that they supported mandatory labels on food containing DNA (Department of Agricultural Economics 2015). That's a lot of labels!

It is important that our broader set of cultural values includes at least as much respect for evidence and objective inquiry as it does for sporting heroes and celebrities. It is not magic, myth or mysticism that will help us build a sustainable future, combat the worst effects of climate change, deflect asteroid collisions, send rockets to Mars, or safely develop human level artificial intelligence, or superintelligence. If the majority of citizens don't learn to think beyond the immediate needs of their communities and countries, our governments will not have the necessary political impetus to plan ahead and work collaboratively to 
solve global problems like climate change, or develop strategies to cushion the blows and upheavals that could be wrought by widespread automation (Ford 2009, Pistono 2012, Yang 2018).

Although Western governments have recently begun to fetishise STEM education and publically emphasise its importance in the modern knowledge economy, there is a major roadblock standing in the way of the successful global spread of scientific literacy. Science is hard and human brains are not optimally wired to think about huge numbers and temporal and physical scales, or phenomena that are invisible to the naked eye. Given a choice between a human story with human actors, or a story involving microbes gallivanting around on our skin and in our guts, we will gravitate to the human story.

To get a majority of humans to value science and take a basic interest in its foundations, we must show how it frames their lives, explains their hardwired biases, emotions, motivations and predilections. We must demonstrate how this knowledge can help them make smarter decisions and think more insightfully about the future in this age of accelerating technosocial evolution. Telling the world to wake up and embrace the STEM revolution because the robots are coming for their jobs is a band-aid solution and a scare tactic. Our social priorities need to extend far beyond trying to make sure as many people as possible remain employable in the age of automation.

A respect and reverence for evidence, reason and empiricism, and an understanding of the biases and limitations that are encoded in human cognition and preferences will place us on higher ground when it comes to making collective decisions and defending ourselves against the modern onslaught of novel and emerging risks. I suggest here that the key to the cultural promotion of the Enlightenment values of reason, empiricism and the pursuit of rigorous scientific knowledge, is to bring science back to the human level and promote it through a unified narrative like Big History, which places life, the universe and everything into a comprehensible framework and renders scientific concepts and phenomena more digestible.

\section{The Awkward Idea of Ranking Knowledge}

Some kinds of knowledge are more important and more useful than others and we should value them higher in our societies and education systems. Claims like this tend to worry people in the humanities who think that hordes of beady-eyed STEM imperialists are coming to wipe art and literature and all things 'humanities' off the face of the planet. They needn't worry. Short of enslaving and oppressing the entire human race, you couldn't expunge art from human societies no matter how hard you tried. People will still write, blog, make videos and design impressive new things even if nobody pays them and even if nobody does humanities degrees. The arts are safe-indeed, they are flourishing in the information age, as there are more avenues than ever to create and share content. Humanities majors like literature are probably not very safe, but that's a separate issue from the survival of the arts themselves, and a subject for another paper.

The point here is that every choice to teach $\mathrm{X}$, is a choice not to teach Y. We don't seem to have a good grasp of this when we talk about educational priorities. If I suggest that teaching Shakespeare to twenty-first century teenagers might not be the best use of their time, English teachers and Shakespeare enthusiasts may get very fired up and passionately explain how wonderful Shakespeare is, how much his work enriched their lives, and how outrageous it is to suggest that literature and the arts are not important. They seem to miss the word best and assume I'm claiming that Shakespeare is garbage and has no value whatsoever (which I'm not).

The point is that for every hour of a school day 
that you teach a class of teenagers about Shakespeare, that's an hour that you're not teaching them millions of other things. If, as a society, we decide to teach Shakespeare in schools, we should be very confident in our belief that this subject is of equal or greater importance than all those other possibilities. We have finite time and finite brain capacity to dedicate to the study or an enormous and ever expanding body of material. We can't know a lot about everything and we have to make hard choices and rank some things as higher cultural knowledge priorities than others.

But what could possibly be more important than for most human beings to understand on a deep evolutionary level where we come from, how we have evolved, what kinds of cognitive biases we are still saddled with, and how we fit into a larger evolutionary framework of physical, chemical, biological, cultural and technological evolution? It should be a universal cultural expectation that human general knowledge includes a knowledge of the age of the universe and the Earth, how stars and planets formed, continental drift, natural and sexual selection, the laws of thermodynamics, and how profoundly nonhuman actors like asteroids, pathogens and ice ages have shaped the course of planetary and biological evolution. This macro-evolutionary history gives us the context to comprehend how and why humans have become a major driver of planetary evolution and accelerating change in the past two hundred and fifty years (Crutzen \& Stoermer 2000; Steffen et al 2015; Zalasiewicz 2011). Understanding how we've got to now sets us up to think more robustly about where we're going, how much influence we have over our actions, and how we can mobilise to try and shape the future for the better.

Now, back to Shakespeare. Of the many possible arguments defending the proposition that exposure to Shakespeare is extremely important, I think the best would state that his work deftly captures universal human traits and shows in dramatic form how social and environmental pressures can drive human beings to regicide, existential despair, or the contemplation of suicide. It's all there: competition, jealousy, love, death, vaulting ambition - human nature in a nutshell. There's just one problem; the evolutionary underpinnings of these facets of human nature are not explained in the texts, as they were not yet understood. Perhaps a discussion of evolution could be brought in to the lessons to great effect? But why explore texts written in old English that many teenagers will find boring and inaccessible when there are millions of other works of art and literature that deal with the same themes? Every choice to teach $\mathrm{X}$ is a choice not to teach Y.

Now let's push the argument about knowledge priorities into more extreme territory with a hypothetical. If every work by Shakespeare and all knowledge of him evaporated overnight, would we have more wars? More cruel and ignorant societies? Would all the power go out? Would there be chaos? I happen to love Shakespeare's work, but my life would not be measurably worse if all traces of it were vaporised tomorrow. If all traces of the internet, electricity, or modern medicine were vaporised, or if we wound scientific knowledge back to its state in the Middle Ages, my life (and yours) would be dramatically, qualitatively worse.

A world where nobody knows anything about Shakespeare, Harry Potter, or Kim Kardashian is not dangerous. The loss of these memes poses no obstacle to long-term human flourishing. But a world where nobody understands evolution, or basic scientific concepts, and where many people distrust scientific findings, is very dangerous. Scientific ignorance and distrust can literally up humanity's existential risk ante. It matters for the whole of humanity that people continue to vaccinate their children. It matters that there is continued political support for research and development in areas that could lead to cures for diseases and extend the human life and healthspans. It 
matters that we don't elect loose cannon leaders who may be more likely to consider a nuclear first-strike. It matters that we have effective global policies in place to that enable us to mobilise immediately in the event of a pandemic.

I argue that in the Western world, our hierarchy of assumed knowledge and values needs to be stripped away and rewritten with science forming a key part of the new foundations. Cultivating a basic knowledge of how evolution works, and how the universe and the world evolved, is more important than many of the things we spend much longer learning, thinking and gossiping about. Such a project will take generations, but significant gains could be made in a single generation if we collectively decide to rank some forms of knowledge and memes higher than others.

\section{Why Big History Should Be a Key Knowledge Priority}

A scientific origin story like Big History can help the global community make sense of the novel phenomena of the modern world, imparting a general knowledge of evolutionary history that places humanity within a 13.8 billion year cosmic continuum (Christian 2005, 2018; Christian Brown and Benjamin 2014). This origin story can also promote an epistemology that emphasises reason, science and empiricism, over magic, myth and mysticism. If a large-scale cultural shift could be effected in knowledge priorities, and if humans learned to think more scientifically and prioritise issues on a global scale, the world could be a safer and more cohesive place. Such a shift might even make the difference between human survival and extinction.

Teaching Big History at Macquarie University in Sydney revealed to me how powerful this origin story could be if it were universally taught to children and adults around the world. Macquarie University is the major global hub of Big History and is home to the
Big History Institute, which is headed by the founding big historian, Professor David Christian. David was my $\mathrm{PhD}$ supervisor, and I taught alongside him for two semesters on Macquarie's flagship first year Big History Course MHIS115: An Introduction to Big History in 2016 and 2017.

For the most part, my Big History classes at Macquarie University were made up of humanities majors, who often told me they hated science in school. At the start of the course, most of them couldn't explain natural selection to me if their lives depended on it. The majority also couldn't explain the difference between a scientific theory and a hypothesis and many of the students throughout the course continually asked, "but isn't evolution just a theory?"

These were smart, educated university students who had no idea how old the Earth or the universe is, how it got here, how organisms are related, or how the struggle for existence works. I also came out of high school not knowing any of that-I don't know how, but it's an alarmingly common story in Australia. When teaching Big History to a cohort of mostly humanities majors, I often wondered: how can we truly call them humanities majors if they don't know anything about the evolutionary history of humans?

Understanding natural and sexual selection, and the selection pressures that have shaped our brains, our physiology and motivations can help us to understand families, bonding, love, competition, war, reciprocal altruism, adultery, virtue signaling, gossip, humble bragging and Twitter mobs - the stuff that our lives are made of. These things do not appear out of thin air and nor does racism, nationalism, or any other form of tribal behaviour. The same goes for civilisations, technologies, and everything else created by humans or studied in human history.

In Big History, we aim to bridge the two cultures divide, bringing the sciences and the humanities 
in closer communion (Snow 1959, Wilson 2013). We do not do this tokenistically, but for the sake of rendering important knowledge about the world more accessible (Christian 2017). It is helpful to harness robust scientific knowledge and use it as a starting point to explore questions of meaning, purpose, ethics and values, which have traditionally been the bread and butter of the humanities. This merging of the two cultures appears to give students a more robust framework to start thinking, not just about what life is and how it evolved, but about how to live well in the Anthropocene- a time when things are changing very fast.

Although my experiences are anecdotal, I believe that Big History is an ideal educational tool to impart scientific knowledge globally, because the delivery method of an origin story appeals to the universal human predilection for storytelling (Corballis 2009, Gottschall 2012, Gottschall \& Sloan Wilson 2005). Most people will never become scientists or experts in particular fields of science. But most people have a deep hunger to find meaning in the world and to orient their lives within a broader framework of existence (Wilson 2013). Big History satisfies the enduring human drives for storytelling, myth making and meaning, but it helps modern humans make sense of the world with reference to the theories and findings of modern science. It is also "the product of a globalized world" and "the first origin story for all humans" (Christian 2017). We need a global worldview like Big History, as it can help humans across continents and cultures find common ground and learn to view each other as kin.

\section{What Do We Teach In Big History?}

The first year undergraduate Big History course at Macquarie University is open to students from all faculties and disciplines. The cohort is large-usually between 150-300 hundred students. The course spans
13 weeks and the students are taken on an epic journey from the big bang to the present and the future.

The course is rapid fire, to be sure, but students are introduced to:

- The big bang and the evolution of the early universe

- Stellar and planetary evolution

- Gravity

- The laws of thermodynamics

- Plate tectonics and continental drift

- The origins of life, biological evolution and natural selection

- Hominid and human evolution

- The rise of collective learning and the accelerating pace of cultural and technological evolution in the Palaeolithic, Neolithic and modern eras

- The rise of a single world system of communication and trade

- The Industrial Revolution

- The Anthropocene and the future

My understanding is that this teaching structure remains in place at Macquarie. Instead of teaching about each topic in isolation, Big History tutors illustrate how all of these phenomena fit together in a larger sequence of billions of years of evolution. They remind students how fleeting and recent all of human life and history is in the larger scheme of space and time and introduce them to the core bodies of evidence that support the leading scientific theories on which Big History is built. Tutors also draw students' attention to knowledge gaps on important questions like when, where and how life originated on Earth, and encourage them to critically evaluate the robustness of the bodies of evidence they encounter.

When I taught Big History at Macquarie, we also primed students to start thinking about the future of human, planetary and cosmic evolution. How did humans muster the power to start shaping the future of 
terrestrial evolution? Are we wise enough to wield the powerful new technologies we have invented? What will become of our planet and the universe long term? And how can our choices today affect how the lives of future generations will unfold? (Christian 2005; Christian, Brown and Benjamin 2014).

By the end of a thirteen week Big History course, it's remarkable how many students wrote in their feedback forms that their worldview had changed. This feedback was heartening, in no small part because these students vote and influence market trends with their consumer behaviour. Many of them will eventually have children and they will have to make choices about what to teach the next generation. Just imagine what a difference it could make to their lives and to society if they didn't start this intellectual awakening in their twenties, but had the tools and frameworks to think about the big picture of evolution and humanity from the get-go.

Of course I can't make concrete claims about how much knowledge big history students retain after completing a tertiary big history unit. The lack of data on the social impacts and benefits of Big History courses is conspicuous - though it is worth pointing out that the discipline is young and has not had the social cachet to attract the interest of education researches until recently. Nevertheless, similarly encouraging preliminary feedback has been reported by Joseph Voros (2018), who teaches Big History at Swinburne University of Technology in Melbourne, Australia. In addition, the Italian education researchers Adalberto Codetta Raiteiri et al (2018) have flagged Big History as a knowledge framework that could play an important role in helping young people develop as global citizens who will be capable of responding to the unique challenges of the twenty-first century.

Seconding the thoughts of the researchers above, I can't help thinking that as long as students of Big History carry away with them some of the gist of the story, some sense of the scale of history, and some feeling that change is an evolutionary constant, they're better off than they were before and more likely to pick up new scientific ideas and keep assimilating them into a larger worldview in the future.

\section{Concluding remarks}

We currently devote a huge proportion of the human-headspace pie to entertaining memes focused on human dramas. There is nothing objectionable about the fact that humans love stories and gravitate to gossip and drama. But it is problematic that we are so enamored with human drama that we allocate little time or headspace to the contemplation of anything else.

I have argued in this paper that it should be a universal cultural expectation that human general knowledge includes a knowledge of the age of the universe and the Earth, how stars and planets formed, continental drift, natural and sexual selection, the laws of thermodynamics, and how profoundly non-human actors like asteroids, pathogens and ice ages have shaped the course of planetary and biological evolution. Among other things, this cosmic evolutionary narrative gives us the context to comprehend how and why humans have become a major driver of planetary evolution and accelerating change in the past two hundred and fifty years (Crutzen \& Stoermer 2000; Steffen et al 2015; Zalasiewicz 2011). Understanding how we've got to now sets us up to think more robustly about where we're going.

If there is only one thing the next generation of students walks away from high school knowing, the evolutionary worldview conveyed through Big History would be my choice over any other single subject area. Whatever a person chooses to do from there, it's relevant, not just in work, but in family life, relationships, future planning and self-understanding. Big History is a modern, scientific map of reality that renders key scientific concepts and theories accessible 
to all. If taught globally, Big History could serve as a much-needed torch against ignorance, superstition and tribal thinking — or to use Carl Sagan's (1996) turn of phrase, act as "a candle in the dark".

\section{References}

Bostrom, Nick. 2002. "Existential Risks: Analyzing Human Extinction Scenarios and Related Hazards." Journal of Evolution and Technology 9(1). https:// jetpress.org/volume9/risks.html.

Bostrom, Nick. 2013. "Existential Risk Prevention as Global Priority." Global Policy 4(1). doi: 10.1111/1758-5899.12002.

Christian, David. 2005. Maps of Time: An Introduction to Big History. Berkeley: University of California Press.

Christian, David. 2017. "What Is Big History?" Journal of Big History 1(1). doi: 10.22339/jbh. v1i1.

Christian, David, Cynthia Stokes Brown, Craig Benjamin. 2014. Big History: Between Nothing and Everything. New York: McGraw Hill.

Corballis, Michael. 2009. "Mental Time Travel and the Shaping of Language." Experimental Brain Research 192(3): 553-560.

Crutzen, Paul and Eugene Stoermer. 2000. "The 'Anthropocene." Global Change Newsletter. $\quad$ http://www.igbp.net/nload/18.31 6f18321323470177580001401/1376383088452/NL41.pdf.

Department of Agricultural Economics. 2015. Food Demand Survey. http://agecon.okstate.edu/faculty/ publications/4975.pdf.
Ford, Martin. 2009. The Lights in the Tunnel: Automation, Accelerating Technology and the Economy of the Future. Acculant Publishing: Kindle.

Gottschall, Jonathan. 2012. The Storytelling Animal: How Stories Make Us Human. Boston: Houghton Mifflin Harcourt.

Pew Research Center. 2013. Public's Knowledge of Science and Technology. http://www.people-press. org/2013/04/22/publics-knowledge-of-science-andtechnology/.

Pew Research Center. 2015. Public and Scientists' Views on Science and Society. http://www.pewinternet. org/2015/01/29/public-and-scientists-views-onscience-and-society/.

Pistono, Frederic. 2012. Robots Will Steal Your Job But That's OK: How to Survive the Economic Collapse and Be Happy. Createspace: Kindle.

Raiteiri, Adalberto Codetta et al. 2018. "Towards a Big History Model for Italian Schools: The Convergence of Knowledge from Many Disciplines." Journal of Big History 3(1): 33-49. doi: 10.22339/jbh. $\mathrm{v} 3 \mathrm{i} 1.3120$.

Sagan, Carl. 1996. The Demon Haunted World: Science as a Candle in the Dark. New York: Random House.

Steffen, Will et al. 2015. "The Trajectory of the Anthropocene: The Great Acceleration." The Anthropocene Review 2(1): 81-98. doi: $10.1177 / 2053019614564785$.

Todd, Benjamin. 2017. "Why Despite Global Progress, Humanity is Probably Facing Its Most Dangerous Time Ever." 80,000 Hours. https://80000hours.org/articles/extinction-risk/. 
Voros, Joseph. 2018. "Big History as a Scaffold for Futures Education." World Futures Review 10(4): 263-278. doi: $\underline{10.1177 / 1946756718783510 .}$.

Wilson, Edward O. 2013 [1998]. Consilience: The Unity of Knowledge. London: Abacus.

Yang, Andrew. The War on Normal People: The Truth About America's Disappearing Jobs and Why Universal Basic Income is Our Future. New York: Hachette Books.

Zalasiewicz, Jan et al. 2011. "The Anthropocene: A New Epoch of Geological Time?" Philosophical Transactions of the Royal Society 369: 835-841. doi: 10.1098/rsta.2010.0339. 
